\title{
Diversity, biogeography and conservation of freshwater mussels (Bivalvia: Unionida) in East and Southeast Asia
}

\author{
Alexandra Zieritz $(\mathbb{D} \cdot$ Arthur E. Bogan - Elsa Froufe • \\ Olga Klishko - Takaki Kondo - Uthaiwan Kovitvadhi • Satit Kovitvadhi • \\ Jin Hee Lee • Manuel Lopes-Lima · John M. Pfeiffer • Ronaldo Sousa • \\ Tu Van Do $\cdot$ Ilya Vikhrev $\cdot$ David T. Zanatta
}

Received: 30 September 2016/Revised: 11 January 2017/Accepted: 22 January 2017/Published online: 6 February 2017

(C) Springer International Publishing Switzerland 2017

\begin{abstract}
Recent research efforts have significantly advanced our knowledge on Asian freshwater mussel (Bivalvia: Unionida) diversity and distribution. Here we provide a modern consensus of the diversity, biogeography and conservation of Unionida in the region comprising East and Southeast Asia (excluding Wallacea) and Asian Russia. A data review confirmed the presence of 228 native and 3 non-
\end{abstract}

Guest editors: Manuel P. M. Lopes-Lima, Ronaldo G. Sousa, Lyuba E. Burlakova, Alexander Y. Karatayev \& Knut Mehler / Ecology and Conservation of Freshwater Bivalves

Electronic supplementary material The online version of this article (doi:10.1007/s10750-017-3104-8) contains supplementary material, which is available to authorized users.

A. Zieritz $(\bowtie)$

School of Environmental and Geographical Sciences, Faculty of Science, University of Nottingham Malaysia Campus, Jalan Broga, 43500 Semenyih,

Malaysia

e-mail: Alexandra.zieritz@nottingham.edu.my

\section{A. E. Bogan}

Research Laboratory, North Carolina State Museum of Natural Sciences, MSC 1626, Raleigh, NC 27699-1626, USA

E. Froufe - M. Lopes-Lima

CIIMAR/CIMAR - Interdisciplinary Centre of Marine and Environmental Research, University of Porto, Terminal de Cruzeiros do Porto de Leixões, Av. General Norton de Matos s/n, 4450-208 Matosinhos, Portugal native Unionida (98\% Unionidae, 2\% Margaritiferidae), rendering the region a global hotspot of freshwater mussel diversity. Species richness was highest in China (particularly Yangtze basin) in absolute numbers and Cambodia when correcting for country area, and decreased gradually towards the south and steeply towards the north and east. Six of the seven unionid subfamilies are native to the region, with species richness peaking in Southeast Asia for Rectidentinae, Gonideinae, Parreysiinae and Modellnaiinae, China for Anodontinae and Unioninae, and Asian Russia for Margaritiferidae. Conservation status and data collected after 1980 were not available for 61 and 24\% of species, respectively. Dams, deforestation and pollution are likely the major threats to mussels in the region, though data in this

O. Klishko

Institute of Natural Resources, Ecology and Cryology, Siberian Branch of Russian Academy of Sciences, Nedorezova 16a, 672014 Chita, Russia

T. Kondo

Division of Natural Sciences, Osaka Kyoiku University, 4-698-1 Asahigaoka, Kashiwara, Osaka 582-8582, Japan

U. Kovitvadhi

Department of Zoology, Faculty of Science, Kasetsart University, Bangkok 10900, Thailand

S. Kovitvadhi

Department of Agriculture, Faculty of Science and Technology, Bansomdejchaopraya Rajabhat University, Bangkok 10600, Thailand 
respect are scarce. The Philippines, Laos, Indonesia, Myanmar and Malaysia are among the countries with the poorest data availability and urgently require research.

Keywords Distribution - Margaritiferidae ·

Mollusca · Russia $\cdot$ Unionoida $\cdot$ Unionidae

\section{Introduction}

Our current understanding of freshwater mussel (Bivalvia: Unionida) diversity in East and Southeast Asia is based on a collection of geographically restricted assessments of varied timeliness and outdated comprehensive reviews concerning the whole region. However, several recent and concerted efforts have begun to modernise the traditional interpretation of freshwater mussel diversity and distribution in the region. Our objective herein is to briefly review historical literature that formed the basis of our traditional understanding, create a modern consensus of the diversity, biogeography and conservation status, and discuss future research directions related to freshwater mussels in East and Southeast Asia.

The scientific study of freshwater mussels in this region started in the mid-nineteenth century. Eduard von Martens, Pierre Marie Heude and Mattheus Marinus Schepman were some of the first researchers who sampled and described freshwater mussel species from East and Southeast Asia, including Japan, Vietnam, China and Borneo (Martens,

\section{J. H. Lee}

Department of Life Science, Kyungpook National University, 80 Daehak-ro, Buk-gu, Daegu 702-701, Korea

M. Lopes-Lima

CIBIO/InBIO - Research Center in Biodiversity and Genetic Resources, Universidade do Porto, Campus Agrário de Vairão, Rua Padre Armando Quintas, 4485661 Vairão, Portugal

\section{J. M. Pfeiffer}

Florida Museum of Natural History, University of Florida, Gainesville, FL, USA

R. Sousa

CBMA - Centre of Molecular and Environmental Biology, Department of Biology, University of Minho, Campus Gualtar, 4710-057 Braga, Portugal
1861, 1867, 1902; Heude, 1875-1885; Dautzenberg \& d'Hamonville, 1887; Schepman, 1896; Martens, Dautzenberg \& Fischer, 1906a, b, 1907). In the early twentieth century, the first significant contributions on the freshwater mussels of Myanmar were published by Preston $(1912,1915)$ and Prashad (1922).

Simpson's $(1900,1914)$ synopsis and catalogue on the whole order and Haas' (1910-1920, 1923) contributions on Asian freshwater mussels represent the first comprehensive works relevant to the present review, as they treated considerable numbers of taxa from the study region. These publications were later updated and complemented by Haas' (1969) and Brandt's (1974) monographs on the whole order and freshwater mussels of Southeast Asia (predominantly Thailand), respectively.

For large parts of Southeast Asia, including Cambodia, Laos, Malaysia, Indonesia and the Philippines, the works listed above still represent the primary sources for scholars interested in the diversity and biogeography of freshwater mussels. For other countries, particularly in East Asia, however, relatively recent monographs on freshwater mussel species-level diversity are available, including Vietnam (Đặng et al., 1980), Russia (Starobogatov et al., 2004; Kantor \& Sysoev, 2005), South Korea (Min et al., 2004), Japan (Kondo, 2008) and China (He \& Zhuang, 2013). The apparent rise in scientific interest in Asian freshwater mussel diversity and conservation around the turn of the twenty first century followed a growing recognition of the endangered status and ecological importance of the relatively well-studied freshwater mussel fauna of North

T. Van Do

Institute of Ecology and Biological Resources, Vietnam Academy of Science and Technology, 18 Hoang Quoc Viet, Ha Noi, Vietnam

I. Vikhrev

IBIGER - Institute of Biogeography and Genetic

Resources, Federal Centre for Integrated Arctic Research, Russian Academy of Sciences, Severnaya Dvina Emb. 23, 163000 Arkhangelsk, Russia

D. T. Zanatta

Biology Department, Institute of Great Lakes Research, Central Michigan University, Mount Pleasant, MI 48859, USA 
America and Europe (Bogan, 1993; Bauer \& Wächtler, 2001; Vaughn \& Hakenkamp, 2001; Lydeard et al., 2004).

The beginning of the twenty first century also witnessed the arrival of the molecular revolution in freshwater mussel research, which resulted in a vastly altered understanding of the evolutionary relationships between freshwater mussel lineages. Graf \& Cummings $(2006,2007)$ presented the first molecular phylogeny and subsequent classification for the Unionida, but resolution of (sub)tropical lineages was limited, particularly for Asia. Since then, further revisions, focused on including representatives from the (sub)tropical and Asian fauna, have substantially refined our understanding of freshwater mussel evolution and their higher-level classification (Zhou et al., 2007; Whelan et al., 2011; Pfeiffer \& Graf, 2013, 2015). Very recently, Lopes-Lima et al. (2017b) published a long-overdue, revised molecular phylogeny of the most species-rich freshwater mussel family Unionidae with much improved taxon sampling, particularly with respect to Asian taxa. That phylogeny, based on a combined dataset of $1032 \mathrm{bp}$ $(\mathrm{COI}+28 \mathrm{~S})$ covering 70 species in 46 genera, divided the Unionidae into 7 subfamilies and 18 tribes, three of which (i.e. Chamberlainiini, Cristariini and Lanceolariini) were newly erected. In addition, the recent focus on Asian freshwater mussels using molecular approaches has improved our understanding of the species-level diversity and distribution, including the recognition of several new -sometimes morphologically cryptic-species (Kongim et al., 2015; Thach, 2016a; Zieritz et al., 2016).

In light of the recent advances in understanding freshwater mussel diversity, distribution and evolution in East and Southeast Asia, an updated review of the current state of knowledge in the region is timely. In this context, knowledge on the numbers and identity of species present across the region is the basis for any further research or conservation efforts. The aims of this review are therefore to (1) provide an up-to-date species inventory of the Unionida for each of the 17 countries of East and Southeast Asia (excluding Wallacea and including Asian Russia), as well as the 26 largest river and lake basins in the region; (2) elucidate differences in availability and quality of data between taxa, countries and basins, and identify those taxa, countries and basins with particularly poor data availability; (3) assess spatial patterns of subfamily and species diversity in the region, and identify the regions of particularly high richness; and (4) based on these findings (objectives 1-3), identify the regions and scientific questions that urgently require further research.

\section{Materials and methods}

Study region and basins

The study region comprises East Asia, Southeast Asia (excluding Wallacea) and Asian Russia (i.e. Russia from the $\mathrm{Ob}$ basin to the east; Fig. 1). The study countries were therefore Brunei, Cambodia, China (including Hong Kong and Macau), Indonesia (West of Wallace's Line = Sumatra, Java and Borneo), Japan, Laos, Malaysia, Mongolia, Myanmar, North Korea, Philippines, Asian Russia, Singapore, South Korea, Thailand, Taiwan and Vietnam. In addition, we analysed data for the 26 largest river and lake basins in the study region (i.e. those with $>50,000 \mathrm{~km}^{2}$ drainage area; Fig. 2): Amur, Ayeyarwady (= Irrawaddy), Baikal, Barito, Chao Phraya, Hai, Hwang Ho (= Yellow River), Indigirka, Kamchatka, Kapuas, Kolyma, Lake Ubsa, Lena, Liao, Mahakam, Mekong, Min, Musi, Ob, Salween, Song Hong (= Red River), Tarim (Yarkand), Xi + Bei (= Pearl River), Xinyi, Yangtze and Yenisei.

\section{Data collection and preparation}

Data on unionoid species presence in a country or basin were gathered from the following groups of sources: (1) records collected personally by at least one co-author; (2) literature (Drouet \& Chaper, 1892; Simpson, 1900; Preston, 1912, 1915; Simpson, 1914; Prashad, 1922; Haas, 1923; Zhadin, 1965; Brandt, 1974; Đặng et al., 1980; Zatravkin \& Bogatov, 1987; Yang, 1990; Deein et al., 2003; Kantor \& Sysoev, 2005; Thach, 2005; Zi-Qiang, 2005; Clements et al., 2006; Thach, 2007; Chan, 2008; Dolgin, 2009; Tan et al., 2012; Thach, 2012; He \& Zhuang, 2013; Kongim et al., 2015; Pfeiffer \& Graf, 2015; Qian et al., 2015; Thach, 2016a, b); (3) museum collections (i.e. California Academy of Sciences, North Carolina Museum of Natural Sciences, Zoological Institute of 
(A)

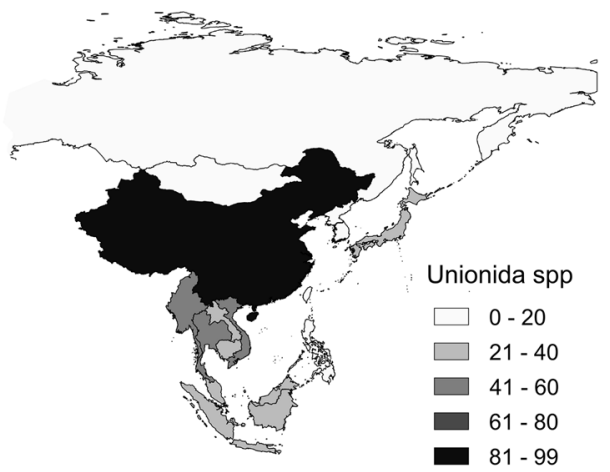

(C)

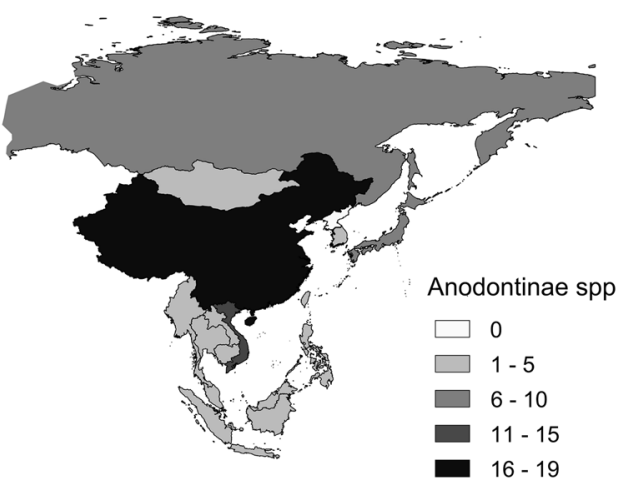

(E)

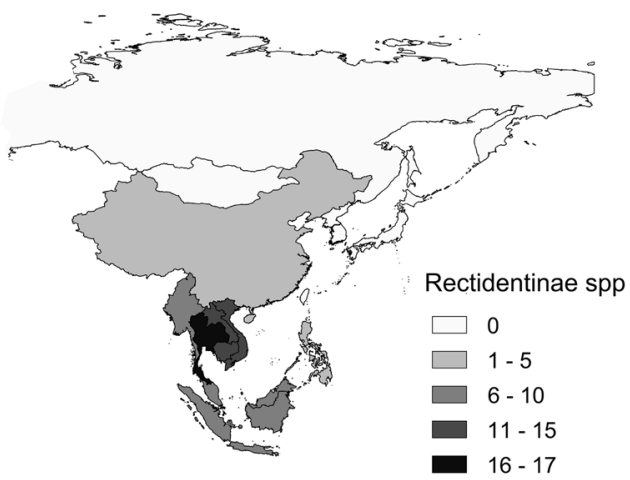

(G)

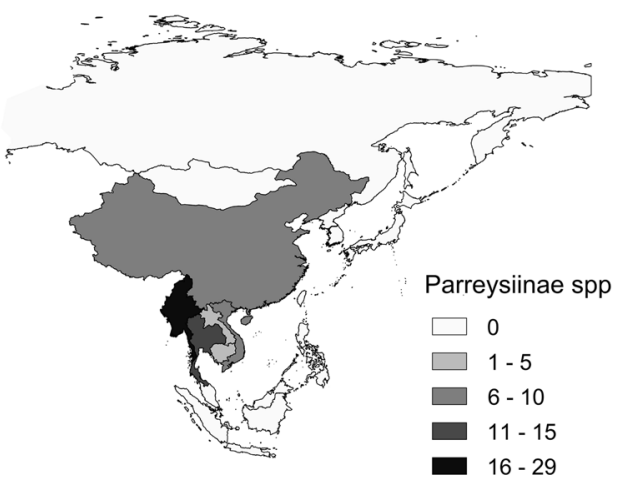

(B)

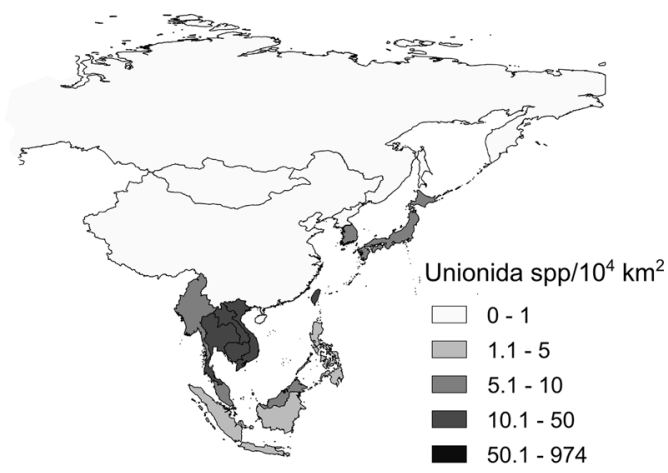

(D)

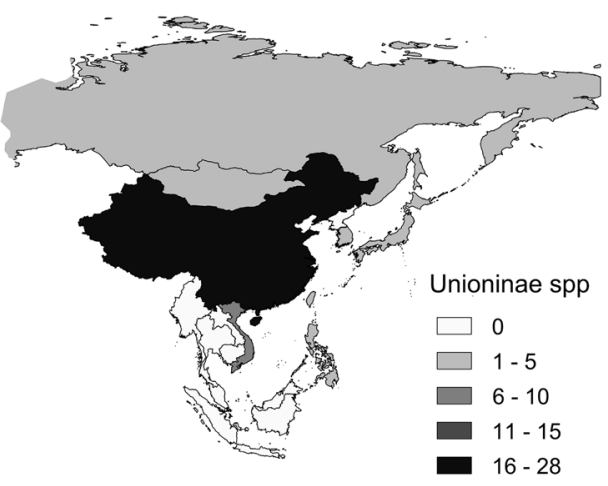

(F)

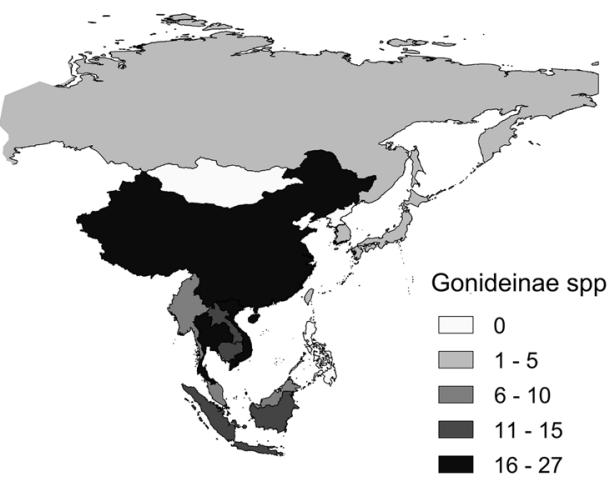

(H)

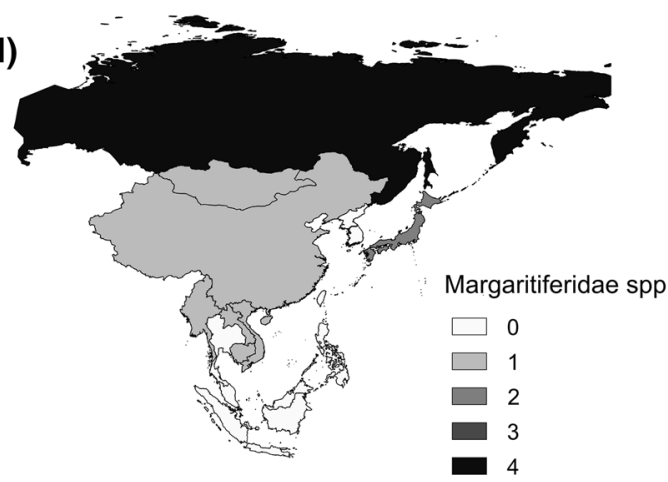


4Fig. 1 Distribution of unionoid species diversity across countries in East and Southeast Asia shown for A Unionida, B Unionida per country area, C Anodontinae, D Unioninae, E Rectidentinae, F Gonideinae, G Parreysiinae and $\mathbf{H}$ Margaritiferidae species

the Russian Academy of Sciences); and (4) the Mussel Project Database (http://mussel-project.uwsp.edu/, Graf \& Cummings, 2015) (using the following search terms for "specimen locality": Amur, Ayeyarwady, Baikal, Barito, Bei, Brunei, Burma, Cambodia, Chaophraya, Chao Phraya, China, Hai, Hong Kong, Hwang Ho, Indigirka, Indonesia, Irrawaddy, Japan, Kamchatka, Kapuas, Kolyma, Korea, Laos, Lena, Liao, Mahakam, Malaysia, Mekong, Min, Mongolia, Musi, Myanmar, Macau, Ob, Pearl, Philippines, Red, Russia, Salween, Singapore, Song Hong, Tarim, Thailand, Taiwan, Ubsa, Vietnam, Xi, Xinyi, Yangtze, Yarkand, Yellow, Yenisei).

If at least one of the above sources indicated the presence of a given species in a given country/basin, the respective cell in the matrix was coded according to the following rules:

(1) If at least one co-author collected the record him-/herself from the field not earlier than 1980 $\rightarrow \mathrm{R}$ (recent).

(2) If at least one co-author has seen a museum specimen or photograph of specimen that was collected not earlier than $1980 \rightarrow \mathrm{R}$ (recent) with reference.

(3) If at least one co-author has seen a museum specimen or photograph of specimen that was collected earlier than $1980 \rightarrow \mathrm{H}$ (historical) with reference.

(4) Record based on literature reference with no specimens or pictures of specimens seen by any co-author $\rightarrow$ L (literature) with reference.

Each cell thereby only contained a maximum of one letter, with " $\mathrm{R}$ " taking priority over " $\mathrm{R}$ with reference", which took priority over " $H$ ", which took priority over "L" (ranked by decreasing reliability of records).

The complete dataset was then reviewed by all coauthors to identify any potentially erroneous records due to, for example, misidentifications and/or mislabelled museum specimens, as well as doubtful records as indicated in Online Resources 1 and 2.
(Potentially) introduced species that are not native in a given country/basin were also indicated in the dataset.

Data on IUCN Conservation Status of species in the study region were gathered from www.iucnredlist. org (IUCN, 2016).

Data analysis and illustration

River basin layers were downloaded and adjusted from projects WRI Major Watersheds of the World at https://worldmap.harvard.edu/data/geonode:wrib asin_1eu and Hydrosheds at http://hydrosheds.cr. usgs.gov. Geopolitical layers were downloaded from DIVA-GIS project at http://www.diva-gis.org/Data. Distribution of freshwater mussel species diversity was mapped for the whole order, and at the family and subfamily levels using the classification of Lopes-Lima et al. (2017b).

\section{Results}

General description of dataset

In total, our dataset indicates the presence of 228 native species from 54 genera, 6 subfamilies and 2 families in the study region (Table 1 ). In addition, 3 non-native amblemine genera and species are present but have been introduced from North America. At the family level, $98 \%$ of species belong to the Unionidae, whereas Margaritiferidae represent only $2 \%$ of the species diversity. Within the Unionidae, the Gonideinae are the most species-rich subfamily in the region, representing 25\% of all unionoid species, followed by Parreysiinae (18\%), Unioninae (16\%), Anodontinae (15\%), Rectidentinae (11\%), Modellnaiinae $(<1 \%)$ and the non-native Ambleminae $(1 \%)$ (Fig. 3A). The unionid subfamily-level position is unknown for $12 \%$ of the species in the region [i.e. incertae sedis (i.s.) Unionidae].

The IUCN conservation status for $42 \%$ of the species has not yet been assessed, and 19\% were assessed as Data Deficient (Fig. 3B). Of the remaining 39\% of species in the region, $29 \%$ were assessed as Least Concern, $1 \%$ as Near Threatened, and 3\% as Vulnerable, Endangered and Critically Endangered, respectively. 
(A)

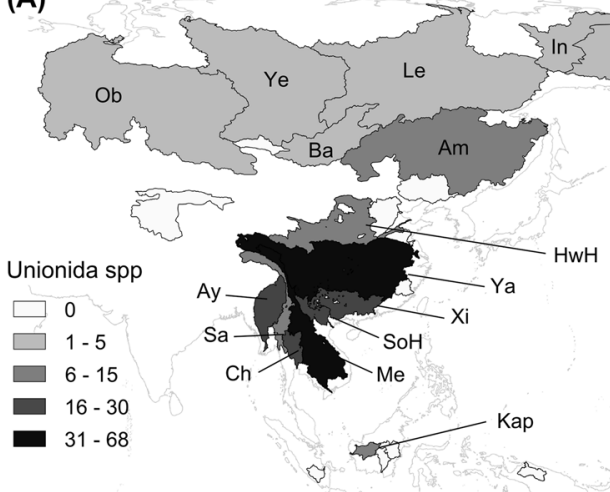

(C)

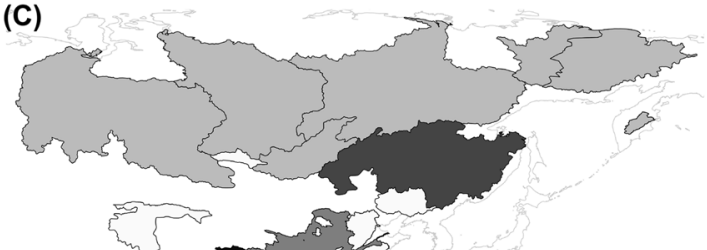

Anodontinae spp

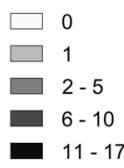

— $11-17$

(E)
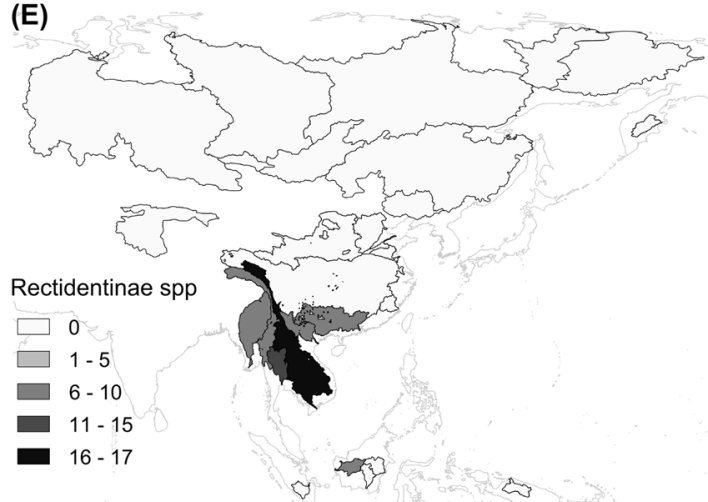

(G)
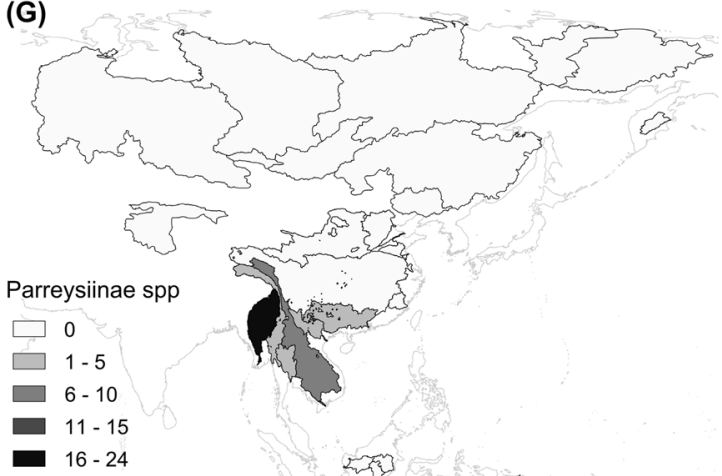

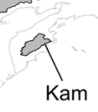

am
(B)

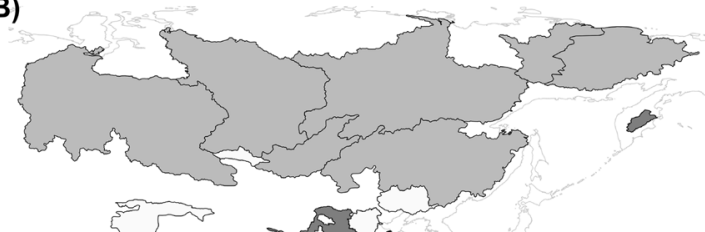

Unionida $\mathrm{spp} / 10^{6} \mathrm{~km}^{2}$

$$
\begin{array}{ll}
\square & 0 \\
\square & 0.1-10 \\
\square & 10.1-50 \\
\square & 50.1-100 \\
\square & 100.1-145
\end{array}
$$

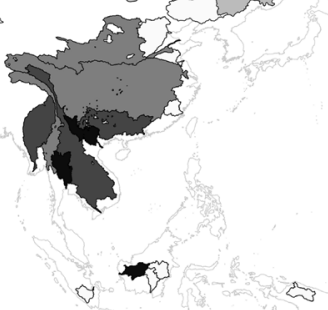

(D)

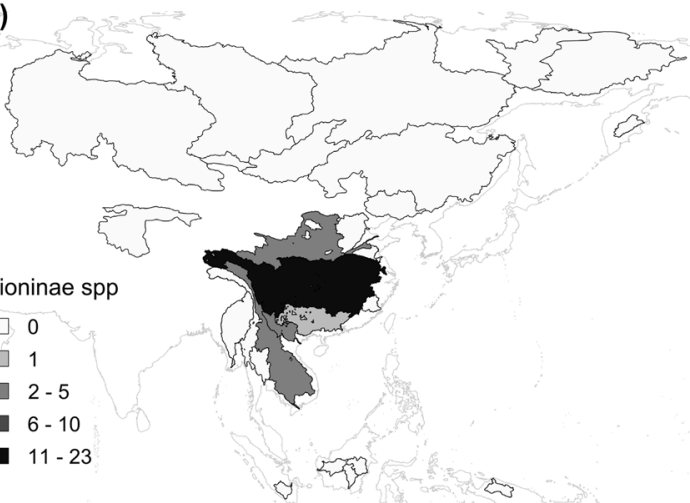

(F)
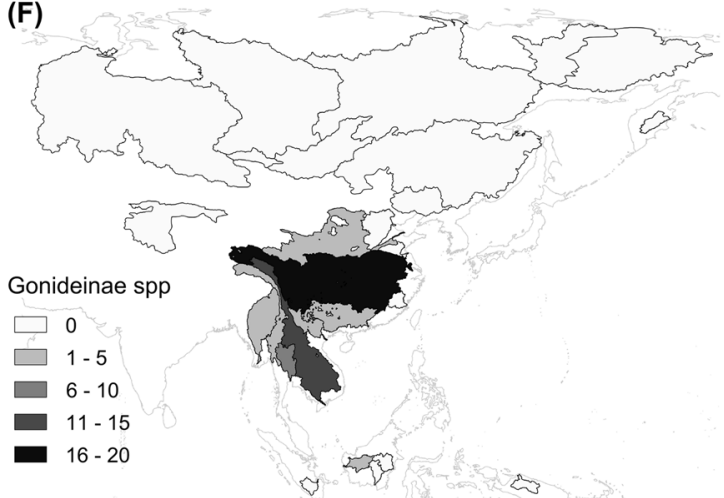

(H)
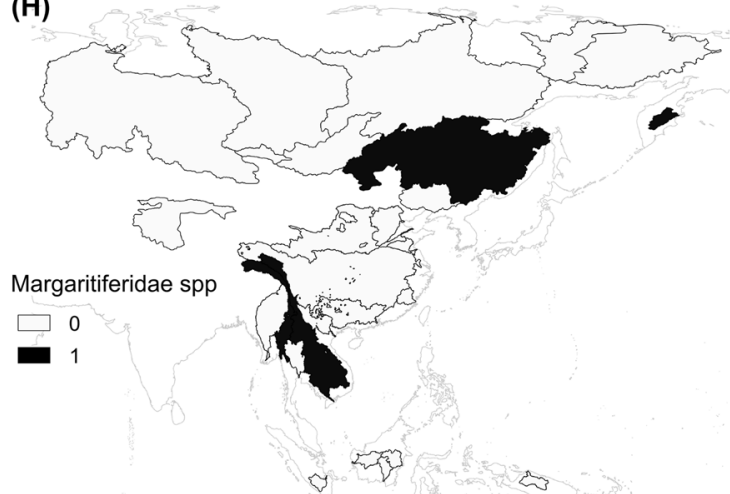
४Fig. 2 Distribution of unionoid species diversity across major river basins in East and Southeast Asia shown for A Unionida, B Unionida per country area, C Anodontinae, D Unioninae, E Rectidentinae, F Gonideinae, G Parreysiinae and $\mathbf{H}$ Margaritiferidae species. Am Amur, $A y$ Ayeyarwady, $B a$ Baikal, $C h$ Chao Phraya, HwH Hwang Ho (= Yellow), In Indigirka, Kam Kamchatka, Kap Kapuas, Ko Kolyma, Le Lena, Me Mekong, $\mathrm{Ob} \mathrm{Ob}, \mathrm{Sa}$ Salween, SoH Song Hong (Red), Xi Xi \& Bei (Pearl), Ya Yangtze, Ye Yenisei

Data quality

For 6 genera (11\%) and 55 species (24\%), no recent data (i.e. collected in or after 1980, see Methods section) were available (Online Resource 1, Fig. 4A). The higher taxa with the most species lacking recent records were the Oxynaiini (11 spp.), followed by Unionidae i.s. (10), Pseudodontini (8), Contradentini (7), Parreysiini (6), Lamellidentini (4), Anodontinae i.s. (2), and Unioninae i.s., Anodontini, Rectidentini, Lamprotulini, Gonideini, Gonideinae i.s. and Modellnaiinae (1 spp. each) (Fig. 4A).

We gathered a total of 459 species-per-country records (Online Resource 1). For 59\% of these records, recent data were available, whereas the remaining $41 \%$ were exclusively based on data predating 1980. Pronounced differences between countries were observed in this respect, so that no recent records were found for the Philippines, Taiwan and Brunei, whilst recent data were lacking for less than $10 \%$ of species present in South Korea, Japan and China (Fig. 4B). In the case of China, however, the bulk of "recent" data are based exclusively on $\mathrm{He} \&$ Zhuang (2013), and the exact date of each of these records is unknown.

We gathered 264 species-per-basin records (Online Resource 2). For $75 \%$ of these records, recent data were available, whereas the remaining $25 \%$ were exclusively based on data pre-dating 1980. As for countries, pronounced differences were present in data quality between river basins. Recent data were completely lacking for the Kapuas, Ob, Yenisei, Lena, Indigirka and Kolyma Rivers, lacking in over $50 \%$ of data for the Salween and Ayeyarwaddy Rivers, and less than that for the Mekong, Song Hong, Chao Phraya, Yangtze, Amur and Kamchatka Rivers (Fig. 4C). All species records from all other river basins for which unionoid presence was confirmed were based on recent data (collected in or after
Table 1 Generic and species diversity of Unionida in East and Southeast Asia

\begin{tabular}{|c|c|c|}
\hline Taxa & $\begin{array}{l}\text { Number of } \\
\text { genera in study } \\
\text { region }\end{array}$ & $\begin{array}{l}\text { Number of } \\
\text { species in study } \\
\text { region }\end{array}$ \\
\hline UNIONIDA & 57 & 231 \\
\hline UNIONIDAE & 56 & 226 \\
\hline Anodontinae & 8 & 34 \\
\hline Anodontini & 1 & 2 \\
\hline Cristariini & 4 & 17 \\
\hline Lanceolariini & 2 & 13 \\
\hline Anodontinae i.s. & 1 & 2 \\
\hline Unioninae & 9 & 37 \\
\hline Unionini & 1 & 3 \\
\hline Unioninae i.s. & 8 & 34 \\
\hline Rectidentinae & 6 & 25 \\
\hline Contradentini & 3 & 16 \\
\hline Rectidentini & 3 & 9 \\
\hline Gonideinae & 10 & 57 \\
\hline Chamberlainiini & 2 & 3 \\
\hline Lamprotulini & 2 & 16 \\
\hline Gonideini & 1 & 6 \\
\hline Pseudodontini & 2 & 28 \\
\hline Gonideinae i.s. & 3 & 4 \\
\hline Parreysiinae & 5 & 42 \\
\hline Parreysiini & 1 & 11 \\
\hline Lamellidentini & 1 & 8 \\
\hline Oxynaiini & 3 & 23 \\
\hline Modellnaiinae & 1 & 1 \\
\hline Ambleminae $^{a}$ & 3 & 3 \\
\hline Unionidae i.s. & 14 & 27 \\
\hline MARGARITIFERIDAE & 1 & 5 \\
\hline
\end{tabular}

i.s. incertae sedis

a Subfamily not native in Asia

1980). No native Unionida could be confirmed for the remaining river basins studied, i.e. the Barito, Mahakam and Musi Rivers in Indonesia, the Hai, Liao, Min, Tarim and Xinyi Rivers in China, and Lake Ubsa, Mongolia.

\section{Distribution of species-level diversity}

With 99 recorded species, China is by far the most unionoid species-rich country, followed by southern neighbours Vietnam, Thailand and Myanmar with 58, 52 and 43 species, respectively (Fig. 1A). Unionoid 
(A) Taxa

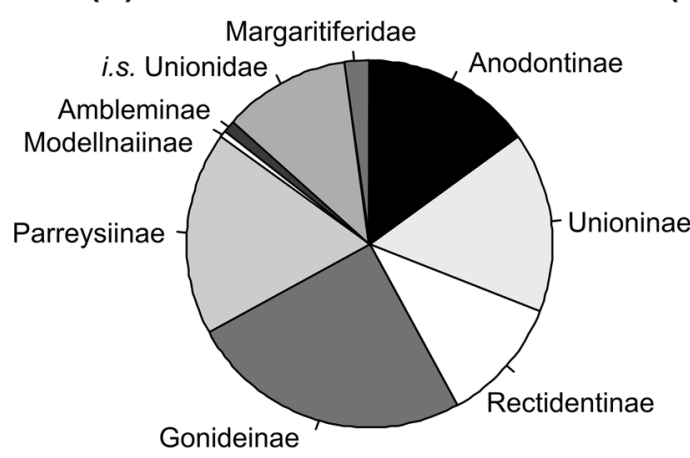

(B) Conservation

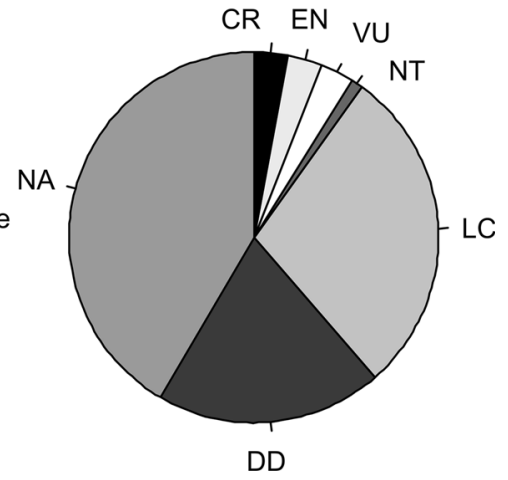

Fig. 3 Relative distribution of East and Southeast Asian freshwater mussel species (Bivalvia: Unionida) across A higher taxa and B IUCN Conservation Statuses. All 231 species present in the region included in A but only 228 native species

species diversity per country decreases relatively gradually towards the south and more steeply towards the north and east. Thus, the Southeast Asian states Cambodia, Laos, Malaysia and Indonesia count 2536 species; the Philippines, South Korea and Japan count 7-21 species; and Mongolia and Russia count 8 and 19 species, respectively.

When controlling for country area and excluding very small and mini-states (i.e. Brunei, Singapore and Taiwan), the epicentre of unionoid species diversity is, however, displaced to the south. Cambodia is the most speciose country for its size in the region, followed by Vietnam, Laos and Thailand (Fig. 1B). From that epicentre, unionoid diversity per area gradually decreases towards the west (i.e. Myanmar), south (i.e. Malaysia and Indonesia) and east (i.e. Philippines, South Korea and Japan). Unionoid diversity per area decreases sharply towards the north and is comparatively low in China, Asian Russia and Mongolia.

When assessing biodiversity patterns by major river basins, the Yangtze and Mekong stand out as the by far most unionoid-speciose basins in the region, counting 68 and 51 species, respectively (Fig. 2A). These were followed by neighbouring basins Ayeyarwady, Chao Phraya, Song Hong and Xi \& Bei with 18 to 29 unionoid species, respectively. Unionoid diversity is slightly lower in the two remaining basins of that cluster, i.e. the Salween (11 spp.) and the Hwang Ho (13 spp.), which attained similar diversity as the more southern Kapuas and more northern Amur basins (with 9 and 14 spp., included in B. $C R$ critically endangered, $D D$ data deficient, $E N$ endangered, i.s. incertae sedis, LC least concern, NA not assessed, $N T$ near threatened, $V U$ vulnerable

respectively) (Fig. 2A). The seven major river and lake basins of Northern Russia were uniform in exhibiting only 1 or 2 unionoid species.

When correcting for basin size, the three smallersized basins Chao Phraya, Song Hong and Kapuas were identified as the basins with the highest unionoid species richness per area (Fig. 2B). The next highest values were found in the Ayeyarwady, Mekong and $\mathrm{Xi} \&$ Bei basins, and only then in the Yangtze, Salween as well as the smaller Kamchatka basin.

\section{Biogeographic patterns}

Based on the species diversity heat maps (Fig. 1), the unionoid subfamilies native to the study region can be grouped into three by major distribution patterns: (1) Southeast Asian epicentre [Rectidentinae, Gonideinae, Parreysiinae, Modellnaiinae (monotypic subfamily confined to Thailand and therefore not depicted)]; (2) Chinese epicentre (Anodontinae, Unioninae) and (3) North Asian epicentre (Margaritiferidae).

\section{Southeast Asian epicentre}

Despite their high species diversity in the region, the Parreysiinae are the subfamily with the most limited distribution in the region, being restricted to an area in mainland Asia extending to China in the north and Thailand in the south (Fig. 1G). With 29 species, the by far highest species diversity of Parreysiinae in the 


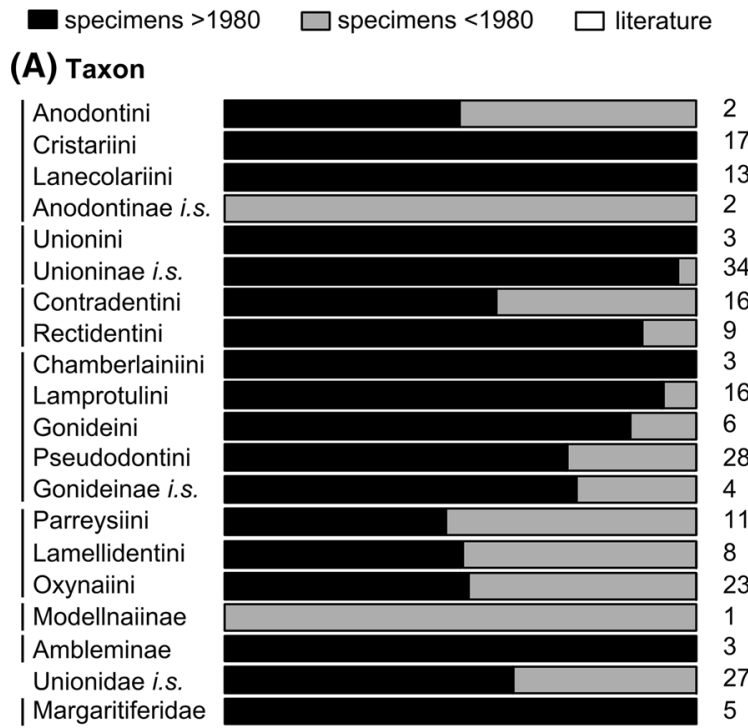

\section{(B) Country}

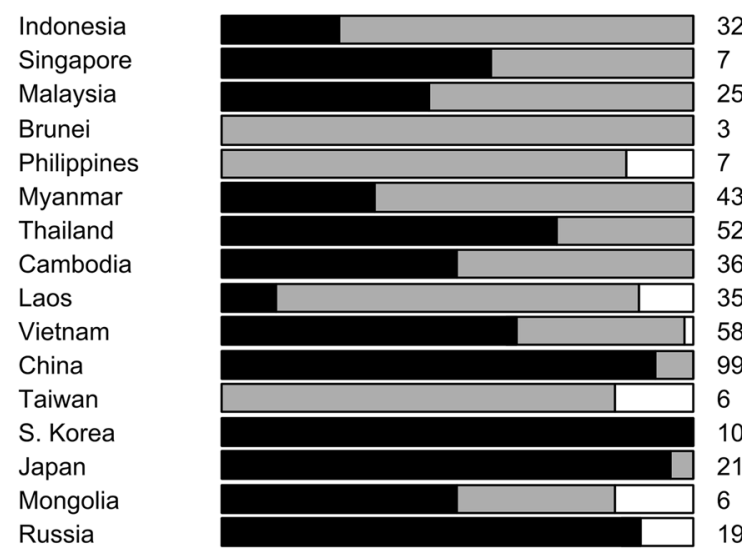

\section{(C) River basin}

\section{Kapuas}

Mekong

Chao Phraya

Salween

Ayeyarwaddy

Song Hong

$X i \& B e i$

Yangtze

Hwang Ho

Baikal

Amur

Kamtchatka

$\mathrm{Ob}$

Yenisei

Lena

Indigirka

Kolyma

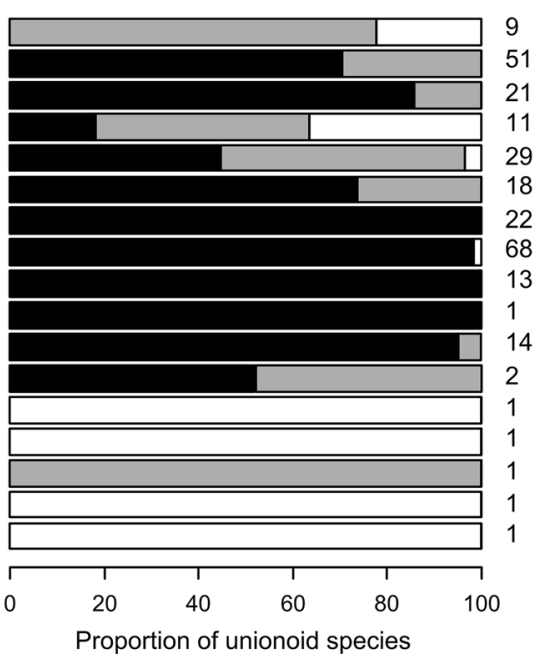

4Fig. 4 Proportion of species for which freshwater mussel records were collected after 1980 (black bars), or only before 1980 with available museum specimens/images (grey bars) or only literature references (white bars), assorted per $\mathbf{A}$ higher taxa (assorted by subfamilies as indicated by black bars on the left), and East and Southeast Asian $\mathbf{B}$ countries and $\mathbf{C}$ major river basins (both listed from southernmost to northernmost country/basin). Numbers to the right of the columns refer to the absolute number of freshwater mussel (Bivalvia: Unionida) species per higher taxon, country or basin, respectively

region is attained in Myanmar; 24 of these species can be found in the Ayeyarwady basin (Fig. 2G).

In comparison to the Parreysiinae, the Rectidentinae are slightly more widespread towards the South and East, with a considerable diversity in Malaysia, Singapore and Indonesia (Fig. 1E). The epicentre of this subfamily is Thailand, and more specifically the Mekong basin, both of which count 17 species (Figs. 3E, 4E).

Together with China (27 spp.) and Vietnam (18 spp.), Thailand (17 spp.) also represents the epicentre of the Gonideinae (Fig. 1F). The highest Gonideinae species diversity is attained in the Yangtze basin with 20 species, followed by the Mekong basin with 14 species (Fig. 2F). The Gonideinae is the subfamily with the widest distribution in the region, and native species records for this subfamily are only lacking for Mongolia and the Philippines. Species diversity decreases gradually to the south of the epicentre and more sharply to the west, north and east.

\section{Chinese epicentre}

The Anodontinae are spread across the entire study region (Fig. 1C), although the southernmost expansion of this subfamily to Malaysia and Indonesia is exclusively due to the introduction of Sinanodonta woodiana (Lea, 1834), native to China. The epicentre of this subfamily is China with 19 species, 17 of which can be found in the Yangtze basin (Fig. 2C). Relatively high anodontine diversity is also present in Vietnam (mostly northern Vietnam), Japan and Asian Russia, hosting 11, 10 and 7 species, respectively (Fig. 1C).

China is also the dominant epicentre of the Unioninae (Fig. 1D). This country hosts 28 species of this subfamily, with 23 species alone being present 
in the Yangtze basin (Fig. 2D). China is followed by Vietnam with 8 species, and no unionine species are known from any other Southeast Asian countries except for one doubtful record of Nodularia douglasiae (Griffith \& Pidgeon, 1833) from the Philippines (Online Resource 1).

\section{North Asian epicentre}

The Margaritiferidae attain their highest species diversity of 4 species in Asian Russia but can be found as far south as Cambodia (Fig. 1H). Our dataset confirms the presence of single margaritiferid species in the Amur, Kamchatka, Salween and Mekong basins (Fig. 2H).

\section{Discussion}

East and Southeast Asia-a global hotspot for unionoid subfamily- and species-level diversity

With 221 native unionoid species (i.e. 228 minus 7 species, which occur only in Asian Russia), East and Southeast Asia is a global hotspot of unionoid diversity. This statement holds true even when compared to Northern America (i.e. the region spanning the United States and Canada), counting 302 species and therefore home to the most diverse unionoid fauna on Earth (Haag, 2012; Table 2). When correcting for size of the two regions, East and Southeast Asia in fact narrowly exceeds Northern America as well as all other major geographic regions of the world in unionoid diversity with 1.40 unionoid species $/ 10^{4} \mathrm{~km}^{2}$ (Table 2). The vast region of Asian Russia, on the other hand, shows exceptionally low unionoid diversity, counting only 19 native species and 0.15 unionoid species $/ 10^{4} \mathrm{~km}^{2}$ (Table 2).

Besides its high species-level diversity, East and Southeast Asia as well as Asian Russia is also a global hotspot for unionoid subfamily-level diversity, including representatives of six of the seven subfamilies of the most species-rich family, i.e. the Unionidae. In comparison, only South America reaches a similar level of higher-level unionoid diversity (Table 2). Against this background, East and particularly Southeast Asia represents an important region for understanding patterns of freshwater mussel diversification and dispersal.

Taxonomic and phylogenetic problems

Whilst our data clearly indicate high unionoid diversity in East and Southeast Asia, actual unionoid species diversity in the region is likely to be even higher. This is suggested by the fact that recently intensified research efforts in the region have led to the discovery of a number of newly recognised species, including Scabies songkramensis from Thailand (Kongim et al., 2015) and Lanceolaria bogani from Vietnam (Thach, 2016a). In addition, molecular tools are continuously revealing morphologically similar (possibly cryptic) species. One recent example is Hyriopsis bialata, which was believed to be a fairly common species, widespread across several major river basins in Southeast Asia, but in fact comprises three different species (Zieritz et al., 2016). Ranges for a number of other species featured in the present work (e.g. in the Southeast Asian genera Pseudodon and Pilsbryoconcha; Online Resources 1 and 2) are also speculative and likely to represent species complexes (J. Pfeiffer, unpublished data). On the other hand, unionoids are notorious for their high intraspecific morphological variability and phenotypic plasticity, as has been shown for a number of well-studied European and North American species (Hornbach et al., 2010; Zieritz et al., 2010). Against this background and considering the lack of high-resolution molecular data for the majority of Asian taxa, there is also a chance that some of the species in the region may actually be lumped in future studies. Unfortunately, conservation efforts at the species level are severely hampered by these taxonomic issues, which concern dozens of unionoid species in the region.

Besides our knowledge gaps with regard to the number and identities of species, there are clear shortcomings in our understanding of the phylogenetic placement of many of the unionoid taxa of the region. For example, our data indicate that the subfamilies of $26 \%$ of all genera and $12 \%$ of all unionoid species in the region have not been resolved yet (Table 1). China, Indonesia and Malaysia show particularly high numbers of such incertae sedis Unionida or Unionidae taxa (i.e. 4-6 genera and 7-10 species). Similarly, a number of recent publications 
Table 2 Comparison of absolute and relative native freshwater mussel (Bivalvia: Unionida) diversity between seven major geographic regions of the world

\begin{tabular}{|c|c|c|c|c|c|c|c|}
\hline & $\begin{array}{l}\text { E and SE-Asia } \\
\text { (combined } \\
\text { values and } \\
\text { separately in } \\
\text { brackets) }\end{array}$ & $\begin{array}{l}\text { Asian } \\
\text { Russia }\end{array}$ & $\begin{array}{l}\text { Northern } \\
\text { America }\end{array}$ & $\begin{array}{l}\text { South } \\
\text { America }\end{array}$ & Europe & Africa & Australasia \\
\hline Area $\left[\right.$ Mio $\left.\mathrm{km}^{2}\right]$ & $\begin{array}{l}15.76 \\
\quad(11.80+3.96)\end{array}$ & 13.1 & 21.98 & 17.84 & 10.18 & 30.3 & 8.77 \\
\hline Unionida spp. & $221(116+135)$ & 19 & 302 & 111 & 16 & $\begin{array}{l}83 \text { (=79 Afrotropical } \\
\text { spp. }+ \\
\text { U. durieui }+ \\
\text { U. foucauldianus }+ \\
\text { U. gibbus }+ \\
\text { U. ravoisieri })\end{array}$ & 32 \\
\hline $\begin{array}{l}\text { Unionida spp./ } \\
10^{4} \mathrm{~km}^{2}\end{array}$ & $\begin{array}{l}1.40 \\
(0.98+3.41)\end{array}$ & 0.15 & 1.37 & 0.62 & 0.16 & 0.27 & 0.36 \\
\hline $\begin{array}{l}\text { Unionida } \\
\text { families }\end{array}$ & $2(2+2)$ & 2 & 2 & $2-3$ & $\begin{array}{l}\text { (unclear status } \\
\text { of Acostea and } \\
\text { Bartlettia) }\end{array}$ & 2 & 3 \\
\hline \multicolumn{8}{|l|}{2} \\
\hline $\begin{array}{l}\text { Unionida } \\
\text { subfamilies }\end{array}$ & $7(6+7)$ & 4 & 3 & $5-7$ & $\begin{array}{l}\text { (unclear status } \\
\text { of Acostea and } \\
\text { Bartlettia) }\end{array}$ & 4 & 5 \\
\hline \multicolumn{8}{|l|}{3} \\
\hline References & This study & $\begin{array}{l}\text { This } \\
\text { study }\end{array}$ & $\begin{array}{l}\text { Graf } \\
\qquad \& \text { Cummings } \\
\text { (2007), Haag } \\
\text { (2012) }\end{array}$ & $\begin{array}{l}\text { Pereira } \\
\text { et al. } \\
(2014)\end{array}$ & $\begin{array}{l}\text { Lopes-Lima } \\
\quad \text { et al. (2017a) }\end{array}$ & $\begin{array}{l}\text { Graf \& Cummings } \\
\text { (2015), Froufe et al. } \\
\text { (2016) }\end{array}$ & $\begin{array}{l}\text { Walker } \\
\text { et al. } \\
(2014)\end{array}$ \\
\hline
\end{tabular}

revealed generic polyphyly of several genera of the region, including Pseudodon (Kondo \& Yamashita, 1980), Lamprotula (Zhou et al., 2007; Pfeiffer \& Graf, 2013) and Solenaia (Lopes-Lima et al., 2017b). These gaps in phylogenetic understanding confound our ability to accurately determine subfamily and generic ranges in the region, especially in Sundaland.

\section{Conservation and threats}

Efforts towards protecting freshwater mussels in East and Southeast Asia are almost non-existent. IUCN conservation status assessment has not been attempted or could not be completed due to a lack of data for $61 \%$ of the unionoid species in the study region. In comparison, this is the case for only $19 \%$ of European and $25 \%$ of Northern American unionoid species (1 and 67 spp. Not Assessed, 2 and 9 spp. Data Deficient, respectively; IUCN, 2016). National Red-lists for Unionida are available for only four of the 17 study countries (i.e. Vietnam, South Korea, Japan and Russia; Table 3). Not one of the 228 unionoid species of the region is protected by international legislation. The lack of Asian freshwater mussel species in the Convention on International Trade in Endangered Species of Wild Fauna and Flora (CITES) is thereby particularly surprising considering the fact that commercial use and trade of these animals is most likely more intense here than anywhere else in the world (Fiske \& Shepherd, 2007; Ali \& Cartier, 2013; Ng et al., 2016). Finally, national protection is in place for only two species in South Korea (Table 3).

To a large part, the lack of protection of freshwater mussel species in East and Southeast Asia is due to the lack of knowledge on their status, threats and other conservation-related issues. Scientific studies specifically investigating threats to and host fish identities of freshwater mussels in the region are particularly rare and restricted to three countries in 
Table 3 National conservation status, protection and data availability on conservation of Unionida in East and Southeast Asian countries

\begin{tabular}{|c|c|c|c|c|}
\hline & Red Data Book & National protection & Major threats & $\begin{array}{l}\text { Knowledge on host fish, } \\
\text { reproductive biology }\end{array}$ \\
\hline Indonesia & No & No & $\begin{array}{l}\text { No published data, but probably } \\
\text { pollution, dam construction, } \\
\text { deforestation and land-use change } \\
\text { (A. Zieritz, pers. obs.) }\end{array}$ & No data \\
\hline Singapore & No & No & Urbanisation (Tan et al., 2012) & No data \\
\hline Malaysia & No & No & $\begin{array}{l}\text { Pollution, deforestation, land-use } \\
\text { change and interaction with non- } \\
\text { native species (Zieritz et al., 2016); } \\
\text { dam construction and mining (A. } \\
\text { Zieritz, pers. obs.) }\end{array}$ & No data \\
\hline Brunei & No & No & No data & No data \\
\hline Philippines & No & No & No data & No data \\
\hline Myanmar & No & No & $\begin{array}{l}\text { No published data, but probably } \\
\text { includes overharvesting (I. Vikhrev, } \\
\text { pers. obs.) }\end{array}$ & No data \\
\hline Thailand & No & No & $\begin{array}{l}\text { No published data, but probably } \\
\text { includes climate change, pollution } \\
\text { and sediment accumulation (U. and } \\
\text { S. Kovitvadhi, pers. obs.) }\end{array}$ & $\begin{array}{l}\text { Very restricted data for a } \\
\text { few species (e.g. Panha, } \\
\text { 1990, 1992; Chaopaknam } \\
\text { et al., 1994) }\end{array}$ \\
\hline Cambodia & No & No & No data & No data \\
\hline Laos & No & No & $\begin{array}{l}\text { Dam construction, deforestation, } \\
\text { pollution, overharvesting (Bolotov } \\
\text { et al., 2014) }\end{array}$ & No data \\
\hline Vietnam & $\begin{array}{l}\text { Yes (2007): } 11 \\
\text { species assessed, of } \\
\text { which } 1 \mathrm{CR}, 1 \mathrm{EN}, \\
6 \mathrm{VU} \text { and } 3 \mathrm{DD}\end{array}$ & No & $\begin{array}{l}\text { Deforestation, mining, overharvesting, } \\
\text { pollution, dam construction and } \\
\text { other hydrological alterations } \\
\text { (Bogan \& Do, 2013) }\end{array}$ & No data \\
\hline China & No & No & $\begin{array}{l}\text { Dam construction and other } \\
\text { hydrological alterations combined } \\
\text { with climate change (Xiong et al., } \\
\text { 2012; Zhang et al., 2012), mining } \\
\text { (Xiong et al., 2012), overharvesting } \\
\text { (D. Zanatta, pers. obs.), pollution } \\
\text { (Shu et al., 2009; Xiong et al., 2012), } \\
\text { draining of wetlands (D. Zanatta, } \\
\text { pers. obs.) }\end{array}$ & $\begin{array}{l}\text { Very restricted data, many } \\
\text { species are likely } \\
\text { generalists (Shu et al., } \\
\text { 2009). }\end{array}$ \\
\hline Taiwan & No & No & No data & No data \\
\hline $\begin{array}{l}\text { North } \\
\text { Korea }\end{array}$ & No & No & No data & No data \\
\hline $\begin{array}{l}\text { South } \\
\text { Korea }\end{array}$ & $\begin{array}{l}\text { Yes (2012): } 7 \text { of } 9 \\
\text { native species VU, } \\
\text { EN or CR }\end{array}$ & $\begin{array}{l}\text { Yes, } 2 \text { species are under } \\
\text { national protection by } \\
\text { the Endangered Wild } \\
\text { Species Class I }\end{array}$ & $\begin{array}{l}\text { No published data, but dam } \\
\text { construction, pollution and } \\
\text { urbanisation (J.H. Lee, pers. obs.) }\end{array}$ & $\begin{array}{l}\text { Known for some species } \\
\text { (e.g. Choi \& Choi, 1965; } \\
\text { Kwon, 1981; Park \& } \\
\text { Kwon, 1995) }\end{array}$ \\
\hline Japan & $\begin{array}{l}\text { Yes (2014): } 13 \text { of } 19 \\
\text { native species NT, } \\
\text { VU, EN or CR }\end{array}$ & No & $\begin{array}{l}\text { Dam construction, pollution, decline of } \\
\text { host fish populations due to } \\
\text { overfishing and introduction of non- } \\
\text { native predators, such as nutria } \\
\text { (Myocastor coypus), hybridisation } \\
\text { with non-native unionoids (Shirai } \\
\text { et al., 2010; Ishida et al., 2015) }\end{array}$ & $\begin{array}{l}\text { Known for most species } \\
\text { (e.g. Awakura, 1968; Itoh } \\
\text { et al., 2010, 2014) }\end{array}$ \\
\hline Mongolia & No & No & No data & No data \\
\hline
\end{tabular}


Table 3 continued

\begin{tabular}{|c|c|c|c|c|}
\hline & Red Data Book & National protection & Major threats & $\begin{array}{l}\text { Knowledge on host fish, } \\
\text { reproductive biology }\end{array}$ \\
\hline Russia & $\begin{array}{l}\text { Yes (latest 2012): } 10 \\
\text { species NT, VU, } \\
\text { EN or CR }\end{array}$ & No & $\begin{array}{l}\text { Overfishing of host fish, pollution, } \\
\text { mining, deforestation, } \\
\text { overharvesting, predation by non- } \\
\text { native muskrats (Ondatra zibethicus) } \\
\text { (Klishko, 2012a; Klishko \& } \\
\text { Bespalaya, 2015) (personal } \\
\text { observation I. Vikhrev and O. } \\
\text { Klishko) }\end{array}$ & $\begin{array}{l}\text { Known for some species } \\
\text { (Kondo \& Kobayashi, } \\
\text { 2005; Klishko, 2012b) } \\
\text { (Bolotov et al., 2014) }\end{array}$ \\
\hline
\end{tabular}

$C R$ critically endangered, $D D$ data deficient, $E N$ endangered, $N T$ near threatened, $V U$ vulnerable

North and East Asia (i.e. Japan, South Korea and Russia; Table 3). For most of the study region, our knowledge in this respect is therefore confined to anecdotal personal observations (Table 3), general studies on threats to freshwater ecosystems and their biota in the region (e.g. Dudgeon, 2000; Dudgeon et al., 2006; Allen et al., 2012; Winemiller et al., 2016) and studies on freshwater mussels in other regions of the world (e.g. Bogan, 1993; Williams et al., 1993; Lopes-Lima et al., 2017a). These sources suggest that the main threats to freshwater mussels in East and Southeast Asia include dam constructions, deforestation and land-use change, mining, eutrophication and pollution, overharvesting, competition with non-native species, climate change and loss of host fishes (Table 3).

Identifying fields and regions for further work

Considering the many gaps in our knowledge and understanding of East and Southeast Asian unionoid diversity, biogeography and conservation status as presented above, it is clear that we urgently need to intensify our research efforts on these animals in the region. According to our dataset, the countries with the poorest recent data availability and thus most urgent need for research are Brunei, the Philippines, Taiwan, Laos, Indonesia, Myanmar, Malaysia and North Korea (Fig. 4). The Kapuas, Salween and Ayeyarwaddy were identified as the major river basins of the region with the least proportion of recent data available. In addition, we failed to recover unionoid records for three large Indonesian (i.e. Barito, Mahakam and Musi) and five large Chinese river basins (i.e. Hai, Liao, Min, Tarim (Yarkland) and Xinyi), as well as Lake Ubsa in Mongolia. With the exception of the highly saline Lake Ubsa, it is unlikely that freshwater mussels are indeed lacking from all of these basins, but rather that records are either not readily available for scientists outside the country or not known to science yet.

The difficulties in conducting field research in aforementioned countries and rivers are often connected with difficult geographical and/or geopolitical situations, as well as a lack of local scientific expertise. However, recently, considerable progress has been made in this respect by Bolotov et al. (2014) in Laos, Konopleva et al. (2015) in Myanmar and Zieritz et al. (2016) in Peninsular Malaysia. Whilst in many cases these efforts were led by scientists from and based outside the study country, successful conservation can only be achieved through collaboration and long-term commitment of local researchers and authorities.

Acknowledgements AZ was supported by a Postdoctoral Research Fellowship by the School of Environmental and Geographical Sciences, University of Nottingham Malaysia Campus. EF was supported by the Portuguese Foundation for Science and Technology (FCT) under grant SFRH/BPD/ $108445 / 2015$.

\section{References}

Ali, S. H. \& L. E. Cartier, 2013. China's Pearl Industry: an Indicator of Ecological Stress. Development \& Society: Asia, Climate Change, Ecosystems.

Allen, D. J., K. G. Smith \& W. R. T. Darwall, 2012. The Status and Distribution of Freshwater Biodiversity in IndoBurma. IUCN, Cambridge.

Awakura, T., 1968. The ecology of parasitic glochidia of the fresh-water pearl mussel, Margaritifera laevis (Haas) (in 
Japanese with English summary). Scientific Report of the Hokkaido Salmon Hatchery 23: 1-21.

Bauer, G. \& K. Wächtler, 2001. Ecology and Evolution of the Freshwater Mussels Unionoida. Springer-Verlag, Berlin.

Bogan, A. E., 1993. Freshwater bivalve extinctions (Mollusca: Unionoida): a search for causes. American Zoologist 33: 599-609.

Bogan, A. E. \& V. T. Do, 2013. Conservation assessment of freshwater bivalves in northern Vietnam. Tentacle 21: 1920.

Bolotov, I., I. Vikhrev, Y. Bespalaya, V. Artamonova, M. Gofarov, Y. S. Kolosova, A. V. Kondakov, A. Makhrov, A. A. Frolov, S. Tumpeesuwan, A. Lyubas, T. Romanis \& K. Titova, 2014. Ecology and conservation of the endangered Indochinese freshwater pearl mussel, Margaritifera laosensis (Lea, 1863) in the Nam Pe and Nam Long rivers, Northern Laos. Tropical Conservation Science 7: 706-719.

Brandt, R. A. M., 1974. The non-marine aquatic Mollusca of Thailand. Archiv fuer Molluskenkunde 105: 1-423.

Chan, S. Y., 2008. A record of a freshwater clam in Singapore (Unionidae-Ensidens ingallsianus ingallsianus (Lea, 1852). Ellipsaria 10: 9-10.

Chaopaknam, B., K. Toopbucha \& A. Nagachinta, 1994. Study on some biological and ecological aspects of freshwater pearl mussel in Kwae Noi River, Kanchanaburi, Thailand (in Thai). Technical paper No 5/1994 Inland Fisheries Division, Department of Fisheries, Ministry of Agriculture, Bangkok. 24.

Choi, K. C. \& S. S. Choi, 1965. Ecological studies on the Lamprotula coreana (1) -on the breeding season and the larvae, glochidia (in Korean). The Korean Journal of Zoology 8: 67-72.

Clements, R., L. P. Koh, T. M. Lee, R. Meier \& D. Li, 2006. Importance of reservoirs for the conservation of freshwater molluscs in a tropical urban landscape. Biological Conservation 128: 136-146.

Đặng, N. T., T. B. Thái \& V. M. Phạm, 1980. Định loại động vật không xương sống nước ngọt Bắc Việt Nam. Nhà Xuất bản Khoa học và Kỹ thuât, Ha Noi.

Dautzenberg, P. \& B. L. d'Hamonville, 1887. Description d'Espècies nouvelle du Tonkin et observations sur quelques autres Mollusques de la même région. Journal de Conchyliologie 35: 213-225.

Dautzenberg, P. \& H. Fischer, 1906a. Contribution a la fauna malacologique de 1'Indo-Chine. Journal de Conchyliologie 54: 145-226.

Dautzenberg, P. \& H. Fischer, 1906b. Liste des Molluques récoltés par M.H. Mansuy en Indo-Chine et au Yunnan et description d'especies nouvelles. Journal de Conchyliologie 53: 343-474.

Dautzenberg, P. \& H. Fischer, 1907. Contribution â la faune malcologique de l'Indo-Chine. Journal de Conchyliologie 54: 145-226.

Deein, G., Y. Unakornsawat, P. Rattanadaeng, C. Sutcharit, B.O. Kong-Im \& S. Panha, 2003. A new species of Solenaia from Thailand (Bivalvia: Unionidae: Ambleminae). The Natural History Journal of Chulalongkorn University 3: 53-58.

Dolgin, V. N., 2009. Freshwater mussels of Siberia [Kizucheniu presnovodnyh molluskov Sibiri]. Vestnik
Tomskogo gosudarstvennogo pedagogicheskogo universiteta 11: 174-180.

Drouet, H. \& M. Chaper, 1892. Voyage de M. Chaper a Bornéo. Unionidae. Mémoires de la Société zoologique de France 5: 145-154.

Dudgeon, D., 2000. The ecology of tropical Asian rivers and streams in relation to biodiversity conservation. Annual Review of Ecology and Systematics 31: 239-263.

Dudgeon, D., A. H. Arthington, M. O. Gessner, Z. Kawabata, D. Knowler, C. Lévêque, R. J. Naiman, A. H. PrieurRichard, D. Soto, M. L. J. Stiassny \& C. A. Sullivan, 2006. Freshwater biodiversity: importance, status, and conservation challenges. Biological Reviews 81: 163182.

Fiske, D. \& J. Shepherd, 2007. Continuity and change in Chinese freshwater pearl culture. Gems \& Gemology 43: 138-145.

Froufe, E., D. V. Gonçalves, A. Teixeira, R. Sousa, S. Varandas, M. Ghamizi, A. Zieritz \& M. Lopes-Lima, 2016. Who lives where? Molecular and morphometric analyses clarify which Unio species (Unionida, Mollusca) inhabit the southwestern Palearctic region. Organisms Diversity and Evolution 16: 597-611.

Graf, D. L. \& K. S. Cummings, 2006. Palaeoheterodont diversity (Mollusca: Trigonioida + Unionoida): what we know and what we wish we knew about freshwater mussel evolution. Zoological Journal of the Linnean Society 148: 343-394.

Graf, D. L. \& K. S. Cummings, 2007. Review of the systematics and global diversity of freshwater mussel species (Bivalvia: Unionoida). Journal of Molluscan Studies 73: 291-314.

Graf, D. L. \& K. S. Cummings, 2015. The Freshwater Mussels (Unionoida) of the World (and other less consequential bivalves), updated 5 August 2015. MUSSEL Project Web Site. Available at http://mussel-project.uwsp.edu/. Accessed 2016.

Haag, W. R., 2012. North American Freshwater Mussels: Natural History, Ecology, and Conservation. Cambridge University Press, Cambridge, UK.

Haas, F., 1910-1920. Die Unioniden. In Küster, H. C. (ed) Systematisches Conchylien-Cabinet von Martini und Chemnitz. vol 9. Bauer und Raspe, Nürnberg, 1-344.

Haas, F., 1923. Beiträge zu einer Monographie der asiatischen Unioniden. Abhandlungen der Senckenbergischen Naturforschenden Gesellschaft 38: 129-203.

Haas, F., 1969. Superfamilia Unionacea. In Mertens, R. \& W. Henning (eds), Das Tierreich (Berlin). de Gruyter \& Co., Berlin: 1-663.

He, J. \& Z. Zhuang, 2013. The Freshwater Bivalves of China. ConchBooks, Harxheim.

Heude, R. P., 1875-1885. Conchyliologie fluviatile de la province de Nanking et de la Chine centrale (10 volumes).

Hornbach, D. J., V. J. Kurth \& M. C. Hove, 2010. Variation in freshwater mussel shell sculpture and shape along a river gradient. American Midland Naturalist 164: 22-36.

Ishida, S., S. Kimura, T. Karasawa, K. Okazaki, T. Hishino \& N. Nagayasu, 2015. Predation on unionid bivalves by the nutria Myocastor coypus in the Yodogawa River and its characteristics inferred from dead shell samples. Bulletin of the Osaka Museum of Natural History 69: 29-40. 
Itoh, T., W. Kakino \& Y. Yoshida, 2010. Host species for glochidia of the freshwater unionid mussel Inversiunio jokohamensis. Venus: The Japanese Journal of Malacology 69: 41-48.

Itoh, T., W. Kakino, M. Toma, H. Fujimoto, K. Sakihara \& H. Kohno, 2014. Host species for glochidia of the freshwater unionid mussel Cristaria tenuis in Ishigakijima Island, Japan. Venus: The Japanese Journal of Malacology 72: 77-87.

IUCN, 2016. IUCN Red List of Threatened Species. Version 2016-2. www.iucnredlist.org. Accessed 2016

Kantor, Y. I. \& A. V. Sysoev, 2005. Catalogue of Molluscs of Russia and Adjacent Countries. KMK Science Press, Moskow.

Klishko, O., 2012a. Mollusca. Part 6 Red Book of the Zabaikalsky Territory, Animals. Novosibirsky Publishing House, Novosibirsk: 207-238.

Klishko, O. K., 2012b. Some data on reproductive biology of the freshwater mussels (Margaritiferidae, Unionidae) and their relationships with bitterlings (Cyprinidae) in Transbaikalye. Byulleten' Dal'nevostochnogo Malakologicheskogo Obshchestva [Bulletin of the Russian Far East Malacological Society] 15(16): 31-55.

Klishko, O. K. \& Y. Bespalaya, Conservation status and threats of existence for species Unio (Bivalvia Unionidae) in the refuge of the Transbaikalia, Russia. In: 2nd International Meeting on Biology and Conservation of Freshwater Bivalves, Buffalo, 2015. p 90.

Kondo, T., 2008. Monograph of Unionoida in Japan (Mollusca: Bivalvia). Special Publication of the Malacological Society of Japan 3: 1-69.

Kondo, T. \& O. Kobayashi, 2005. Revision of the genus Margaritifera (Bivalvia: Margaritiferidae) of Japan, with description of a new species. Venus: The Japanese Journal of Malacology 64: 135-140.

Kondo, T. \& J. Yamashita, 1980. Morphology of the glochidium of Pseudodon omiensis Heimburg. Venus: The Japanese Journal of Malacology 39: 187-189.

Kongim, B., C. Sutcharit \& S. Panha, 2015. Cytotaxonomy of unionid freshwater mussels (Unionoida, Unionidae) from northeastern Thailand with description of a new species. ZooKeys 514: 93-110.

Konopleva, E., A. Kondakov, I. Vikhrev, Y. Bespalaya, T. S. \& I. Bolotov, 2015. Biogeography of freshwater mussels (Bivalvia: Unionoida) across the largest Southeast Asian riverbasins: Endemism and biodiversity assessment. In: Mehler, K., L. E. Burlakova, A. Y. Karatayev \& S. Dickinson (eds) 2nd International Meeting on Biology and Conservation of Freshwater Bivalves. Great Lakes Center, Buffalo: 32

Kwon, O. K., 1981. The ecological studies on the molluscs in the lake Uiam (1) - on the attachment of the glochidia of A. fukudai to the fish (in Korean). Korean Journal of Limnology 14: 21-25.

Lopes-Lima, M., R. Sousa, J. Geist, D. C. Aldridge, R. Araujo, J. Bergengren, Y. Bespalaya, E. Bódis, L. Burlakova, D. Van Damme, K. Douda, E. Froufe, D. Georgiev, C. Gumpinger, A. Karatayev, Ü. Kebapçi, I. Killeen, J. Lajtner, B. M. Larsen, R. Lauceri, A. Legakis, S. Lois, S. Lundberg, E. Moorkens, G. Motte, K.-O. Nagel, P. Ondina, A. Outeiro, M. Paunovic, V. Prié, T. von Proschwitz,
N. Riccardi, M. Rudzīte, M. Rudzītis, C. Scheder, M. Seddon, H. Şereflişan, V. Simić, S. Sokolova, K. Stoeckl, J. Taskinen, A. Teixeira, F. Thielen, T. Trichkova, S. Varandas, H. Vicentini, K. Zajac, T. Zajac \& S. Zogaris, 2017a. Conservation status of freshwater mussels in Europe: state of the art and future challenges. Biological Reviews 92: 572-607. doi:10.1111/brv.12244.

Lopes-Lima, M., E. Froufe, M. Ghamizi, K. Mock, Ü. Kebapçi, O. Klishko, S. Kovitvadhi, U. Kovitvadhi, O. S. Paulo, J. M. Pfeiffer, M. Raley, N. Riccardi, H. Şereflişan, R. Sousa, A. Teixeira, V. T. Do, S. Varandas, X. Wu, D. T. Zanatta, A. Zieritz \& A. Bogan, 2017b. Phylogeny of most species rich freshwater bivalve family (Bivalvia: Unionida: Unionidae): Defining modern subfamilies and tribes. Molecular Phylogenetics and Evolution 106: 174-191.

Lydeard, C., R. H. Cowie, W. F. Ponder, A. E. Bogan, P. Bouchet, S. A. Clark, K. S. Cummings, T. J. Frest, O. Gargominy, D. G. Herbert, R. Hershler, K. E. Perez, B. Roth, M. Seddon, E. E. Strong \& F. G. Thompson, 2004. The global decline of nonmarine mollusks. Bioscience 54: 321-330.

Martens, E. V., 1861. Die Japanischen Binnenschnecken im Leidner Museum. Malakozoologische Blätter 7: 32-61.

Martens, E. V., 1867. Ueberblick der Najadeen des indischen Archipels. Malakozoologische Blätter 14: 10-17.

Martens, E. V., 1902. Neue Unioniden aus Tonkin und Anam. Nachrichtsblatt der Deutschen Malakozoologischen Gesellschaft 34: 130-135.

Min, D.-K., J.-S. Lee, D.-B. Koh \& J.-K. Je, 2004. Mollusks in Korea. Min molluscan research institute, Seoul: 410-415.

Ng, T. H., S. K. Tan, W. H. Wong, R. Meier, S. Y. Chan, H. H. Tan \& D. C. Yeo, 2016. Molluscs for sale: assessment of freshwater gastropods and bivalves in the ornamental pet Trade. PLoS ONE 11: e0161130. doi:10.1371/ journal.pone.0161130.

Panha, S., 1990. The site survey and the study on reproductive cycles of freshwater pearl mussels in the central part of Thailand. Venus: The Japanese Journal of Malacology 49: 240-257.

Panha, S., 1992. Infection experiment of the glochidium of a freshwater pearl mussel, Hyriopsis (Limnoscapha) myersiana (Lea 1856). Venus: The Japanese Journal of Malacology 51: 303-314.

Park, G. M. \& O. K. Kwon, 1995. Seasonal gonadal cycle of the seven species of freshwater Unionidae (Pelecypoda: Unionoida) (in Korean). Korean Journal of Malacology 11: 147-163.

Pereira, D., M. C. D. Mansur, L. D. S. Duarte, A. S. de Oliveira, D. M. Pimpão, C. Callil, C. Ituarte, E. Parada, S. Peredo, G. Darrigran, F. Scarabino, C. Clavijo, G. Lara, I. C. Miyahira, M. T. R. Rodriguez \& C. Lasso, 2014. Bivalve distribution in hydrographic regions in South America: historical overview and conservation. Hydrobiologia 735: 15-44.

Pfeiffer, J. M. \& D. L. Graf, 2013. Re-analysis confirms the polyphyly of Lamprotula Simpson, 1900 (Bivalvia: Unionidae). Journal of Molluscan Studies 79: 249-256.

Pfeiffer, J. M. \& D. L. Graf, 2015. Evolution of bilaterally asymmetrical larvae in freshwater mussels (Bivalvia: Unionoida: Unionidae). Zoological Journal of the Linnean Society 175 : $307-318$. 
Prashad, B., 1922. A revision of the Burmese Unionidae. Records of The Indian Museum 24: 91-111.

Preston, H. B., 1912. A catalogue of the Asiatic naiades in the collection of the Indian Museum, Calcutta, with descriptions of new species. Records of The Indian Museum 7: 279-308.

Preston, H. B., 1915. Mollusca (Freshwater Gastropoda \& Pelecypoda). Fauna of British India, Including Ceylon and Burma. Taylor and Francis, London.

Qian, Z., Y. Fang \& J. He, 2015. Description of two new freshwater mussels from China. Shell Discoveries 1: $32-$ 33.

Schepman, M. M., 1896. Zoological results of the Dutch Scientific expedition to Central Borneo. The Mollusca of the Dutch Scientific Borneo-expedition. Notes from the Leyden Museum 17: 145-162.

Shirai, A., T. Kondo \& T. Kajita, 2010. Molecular markers reveal genetic contamination of endangered freshwater pearl mussels in pearl culture farms in Japan. Venus: The Japanese Journal of Malacology 68: 151-163.

Shu, F.-Y., H.-J. Wang, B.-Z. Pan, X.-Q. Liu \& H.-Z. Wang, 2009. Assessment of species status of mollusca in the mid-lower Yangtze lakes. Acta Hydrobiologica Sinica 33: 1051-1058.

Simpson, C. T., 1900. Synopsis of the naiades, or pearly freshwater mussels. Proceedings of the United States National Museum 22: 501-872.

Simpson, C. T., 1914. A Descriptive Catalogue of the Naiads, or Pearly Fresh-water Mussels. Part I-III. Bryant Walker, Detroit, MI.

Starobogatov, Y. I., L. A. Prozorova, V. V. Bogatov \& E. M. Sayenko, 2004. Bivalvia. Key to Freshwater Invertebrates of Russia and Adjacent Lands), vol. 6: Mollusks, Polychaetes, Nemerteans. Nauka, St. Petersburg.

Tan, S. K., S. Y. Chan \& G. R. Clements, 2012. A Guide to Snails and other Non-marine Molluscs of Singapore. Science Centre, Singapore.

Thach, N. N., 2005. Shells of Vietnam. ConchBooks, Hackenheim.

Thach, N. N., 2007. Recently collected shells of Vietnam. L'Informatore Piceno, Ancona.

Thach, N. N., 2012. New Records of Molluscs from Vietnam. 48HrBooks Company, Akron, $\mathrm{OH}$.

Thach, N. N., 2016a. Lanceolaria bogani (Bivalvia: Unionidae), a new species from Vietnam. Novapex 17: 9-11.

Thach, N. N., 2016b. Vietnamese New Mollusks: SeashellLandsnails-Cephalopods, with 59 New Species. 48HrBooks Company, Akron, $\mathrm{OH}$.

Vaughn, C. C. \& C. C. Hakenkamp, 2001. The functional role of burrowing bivalves in freshwater ecosystems. Freshwater Biology 46: 1431-1446.

Walker, K. F., H. A. Jones \& M. W. Klunzinger, 2014. Bivalves in a bottleneck: taxonomy, phylogeography and conservation of freshwater mussels (Bivalvia: Unionoida) in Australasia. Hydrobiologia 735: 61-79.
Whelan, N. V., A. J. Geneva \& D. L. Graf, 2011. Molecular phylogenetic analysis of tropical freshwater mussels (Mollusca: Bivalvia: Unionoida) resolves the position of Coelatura and supports a monophyletic Unionidae. Molecular Phylogenetics and Evolution 61: 504-514.

Williams, J. D., M. L. Warren Jr., K. S. Cummings, J. L. Harris \& R. J. Neves, 1993. Conservation status of freshwater mussels of the United States and Canada. Fisheries 18: 622.

Winemiller, K. O., P. B. McIntyre, L. Castello, E. FluetChouinard, T. Giarrizzo, S. Nam, I. G. Baird, W. Darwall, N. K. Lujan, I. Harrison, M. L. J. Stiassny, R. A. M. Silvano, D. B. Fitzgerald, F. M. Pelicice, A. A. Agostinho, L. C. Gomes, J. S. Albert, E. Baran, M. Petrere, C. Zarfl, M. Mulligan, J. P. Sullivan, C. C. Arantes, L. M. Sousa, A. A. Koning, D. J. Hoeinghaus, M. Sabaj, J. G. Lundberg, J. Armbruster, M. L. Thieme, P. Petry, J. Zuanon, G. T. Vilara, J. Snoeks, C. Ou, W. Rainboth, C. S. Pavanelli, A. Akama, A. V. Soesbergen \& L. Sáenz, 2016. Balancing hydropower and biodiversity in the Amazon, Congo, and Mekong. Science 351: 128-129.

Xiong, L., S. Ouyang \& X. Wu, 2012. Fauna and standing crop of freshwater mussels in Poyang Lake, China. Chinese Journal of Oceanology and Limnology 30: 124-135.

Yang, S. L., 1990. Record of a freshwater bivalve, Pseudodon vondembuschianus (Mollusca: Unionidae), in Singapore. Raffles Bulletin of Zoology 38: 83-84.

Zatravkin, M. N. \& V. V. Bogatov, 1987. Large Bivalve Molluscs of Fresh and Brackish Waters of the Far East USSR. Far East Branch. Academy of Science USSR, Vladivostok.

Zhadin, V. I., 1965. Mollusks of fresh and brackish waters of the USSR. Academy of Sciences of the USSR Press, Moscow.

Zhang, Q., L. Li, Y. G. Wang, A. D. Werner, P. Xin, T. Jiang \& D. A. Barry, 2012. Has the Three-Gorges Dam made the Poyang Lake wetlands wetter and drier? Geophysical Research Letters 39: L20402. doi:10.1029/2012GL053431.

Zhou, C.-H., S. Ouyang, X.-P. Wu \& M. Li, 2007. Phylogeny of the genus Lamprotula (Unionidae) in China based on mitochondrial DNA sequences of 16S rRNA and ND1 genes. Acta Zoologica Sinica 53: 1024-1030.

Zieritz, A., J. I. Hoffman, W. Amos \& D. C. Aldridge, 2010. Phenotypic plasticity and genetic isolation-by-distance in the freshwater mussel Unio pictorum (Mollusca: Unionoida). Evolutionary Ecology 24: 923-938.

Zieritz, A., M. Lopes-Lima, A. E. Bogan, R. Sousa, S. Walton, K. A. Rahim, J.-J. Wilson, P.-Y. Ng, E. Froufe \& S. McGowan, 2016. Factors driving changes in freshwater mussel (Bivalvia, Unionida) diversity and distribution in Peninsular Malaysia. Science of the Total Environment 571: 1069-1078.

Zi-Qiang, H., 2005. Geographical distribution of endemic species of Chinese freshwater bivalves. Chinese Journal of Zoology 40: 80-83. 